\title{
REFLECTIONS
}

\section{Answered Prayer}

Charles Morris, MD

California Pacific Medical Center, San Francisco, CA, USA.

$J$ Gen Intern Med 23(3):348

DOI: $10.1007 / \mathrm{s} 11606-007-0420-0$

(C) Society of General Internal Medicine 2007

$\mathrm{D}$ elivered to us without a sound, my breath held yours long gone his never present.

Too soon, too raw, no wail or suckle to be heard just the color blue on every fingertip I countedrubbing as I wentto impart some life, mine to yours take it all.

Finally the breathing tube inserted to force in the world you hesitated to accept,

\author{
lungs prematurely sticky \\ like unopened buds \\ in a frigid March, \\ cut and vased \\ while we waited \\ for them to inspire the sun. \\ Your chest heaved faster \\ than I could count \\ or cry your name \\ Eli, \\ answered prayer, \\ your future written \\ on chromosomes finer than \\ crossed hairs \\ more fragile than the autumn leaf \\ rocking on the window ledge. \\ One mistake in there \\ by our ancestors \\ or those doctors \\ could have ended your beginning, \\ except that I will never \\ let go of the hand \\ you've already closed \\ around my heart.
}

Received September 9, 2007 